\title{
Boron, Fluoride and Copper Distribution in Treated Sugi Sapwood and Heartwood: Interactions Between the Elements
}

\author{
Saip Nami KARTAL ${ }^{1 *}{ }^{*}$, Evren TERZİ ${ }^{1}$ (]) Tsuyoshi YOSHIMURA² \\ ${ }^{1}$ Istanbul University-Cerrahpasa, Faculty of Forestry, Bahceköy, Istanbul, TURKEY \\ ${ }^{2}$ Kyoto University - RISH, Kyoto, JAPAN \\ *Corresponding Author: snkartal@istanbul.edu.tr
}

Received Date: 10.10 .2019

Accepted Date: 13.02 .2020

\begin{abstract}
Aim of study: This study evaluated the distribution of boron (B), fluoride (F) and copper $(\mathrm{Cu})$ elements in sugi wood by single and double treatments and the effect of each element on the elemental distribution in double treatments.

Material and method: The holes in sugi sap- and heartwood specimens were filled with $6 \mathrm{ml}$ of either DOT, $\mathrm{NaF}$ or $\mathrm{CuSO}_{4}$ solutions (2 and 5\%) in single treatments. Some specimens were similarly treated with DOT $+\mathrm{NaF}$, DOT $+\mathrm{CuSO}_{4}$ and $\mathrm{NaF}+\mathrm{CuSO}_{4}$ solutions as double treatments. After conditioning periods of 7, 30, 60 and 90 days, the specimens were cut to three equal assay zones and element distribution was determined in these assay zones.

Main results: Incorporation of the elements in double treatments generally had no adverse effects on element distribution and in most cases they helped each other to obtain higher element levels in the assay zones. However, in double treatments, presence of $\mathrm{Cu}$ negatively affected $\mathrm{F}$ content.

Research highlights: Except for the adverse effects of $\mathrm{Cu}$ on $\mathrm{F}$ element diffusion, there was no negative effect of $\mathrm{B}, \mathrm{F}$ and $\mathrm{Cu}$ elements on each other in the treatments. In most cases, incorporation of the elements improved the diffusion of each one.

Keywords: Boron, Fluoride, Copper, Remedial Treatments, Interaction
\end{abstract}

\section{Sugi Diri ve Öz Odununda Bor, Flor ve Bakır Dağılımı: Elementler Arasındaki Etkileşimler}

$\ddot{O} \mathbf{z}$

Çalışmanın amacı: Bu çalışmada, tek ve ikili işlemlerle bor (B), florür (F) ve bakır $(\mathrm{Cu})$ elementlerinin sugi ağacının diri ve öz odunundaki dağılımını ve her bir elementin ikili işlemdeki element dağılımı üzerindeki etkisi değerlendirilmiştir.

Materyal ve yöntem: Sugi diri ve öz odun örneklerinde açılan delikler, tek işlemlerde $6 \mathrm{ml} \% 2$ ve \% 5 olmak üzere iki grup olarak DOT (di-sodyum oktoborat tetrahidrat), $\mathrm{NaF}$ (sodyum florür) ya da $\mathrm{CuSO}_{4}$ (bakır sülfat) çözeltileri ile doldurulmuştur. Dual işlemlerde ise her bir bileşikten 3'er ml alınarak ikili çözeltiler hazırlanarak deliklere doldurulurmuştur. $7,30,60$ ve 90 günlük şartlandırma periyotlarından sonra, örneklerden üç analiz bölgesinden örnek alınmış ve bu örneklerdeki element dağılımı belirlenmiştir.

Temel sonuçlar: Sonuçlar, elementlerin çift işlemlere dahil edilmesinin genellikle element dağılımı üzerinde olumsuz bir etkisi olmadığını ve çoğu durumda test bölgelerinde daha yüksek element seviyeleri elde etmelerinde yardımcı olduklarını göstermiştir. Bununla birlikte, ikili işlemde, $\mathrm{Cu}$ varlığı, iki element arasında ters etkileşime işaret eden $\mathrm{F}$ içeriğini olumsuz yönde etkilediği belirlenmiştir.

Araştırma vurguları: $\mathrm{Cu}$ elementinin $\mathrm{F}$ elementinin difüzyonu üzerindeki olumsuz etkisi haricinde, B, $\mathrm{F}$ ve $\mathrm{Cu}$ elementlerinin uygulamalarda birbirleri üzerinde olumsuz bir etkisi olmamıştır. Çoğu durumda, element çiftlerinin varlığı, her birinin odun içerisindeki difüzyonunu iyileştirmiştir.

Anahtar kelimeler: Bor, Flor, Bakır, Yerinde Bakım, Etkileșim

\section{Introduction}

Of several control and preventing methods against biodeterioration and biodegradation in buildings, preservative treatment of wood and wood-based building materials to prevent biological attack is one of the most common and effective methods. As a part of preservative techniques, remedial treatments use non-pressure, diffusible chemicals in applications since 
such chemicals move slowly through water within the wood and do not fix themselves in the wood (Kartal et al., in press; Lebow \& Anthony, 2012). Pavia (2006) has reviewed that chemicals placed in the wood only by diffusion are susceptible to leaching, because chemicals that diffuse into the wood matrix can easily leach out during service. The double-diffusion process was thus developed to overcome leaching issues with the singlediffusion processes. In this method, wood is sequentially soaked in two aqueous chemical solutions that react within the wood matrix to form a precipitate that is greatly resistant to leaching and effective to wood degrading organisms.

Boron (B) has long been used in diffusion processes for treatment of building frames while fluoride $(\mathrm{F})$ has been employed to treat wooden windows and door-frames (Freitag \& Morrell, 2005). Boron-based remedial treatments posses several advantages for protecting wood against biodeterioration such as high efficacy of B compounds against both decay fungi and insects, and being their relatively low toxicity to humans, and being odorless and colorless (Terzi et al., 2017). Tasciogl et al. (2017) have stated that sodium fluoride $(\mathrm{NaF})$, a colorless, odorless, non-corrosive crystalline solid, has been used effectively in Europe and the USA against wood-degrading organisms in both preventive and remedial treatments since it diffuses via free water through wood. Fluoride has a long history of use as a diffusible wood preservative and was a main part in the firstly developed diffusible preservative employed in North America (Morrell et al., 2005).

Morrell et al. (2005) have stated that double diffusion is one alternative process for protecting wood of which interest for lower value timbers has been renewed in recent years using $\mathrm{F}$ as a substitute for chromium $(\mathrm{Cr})$. Water-borne copper $(\mathrm{Cu})$ wood preservatives can also diffuse into wood, but diffusion of $\mathrm{Cu}$ is more limited than that of $\mathrm{F}$ since some amount of $\mathrm{Cu}$ reacts with the wood to become fixed (Morrell et al., 2005; Cooper, 1991). In contrast, F and B elements are not strongly fixed to the wood, they remain at protective levels for many years following surface or dipping applications.

This study has focused on the possible interactions among $\mathrm{B}, \mathrm{F}$ and $\mathrm{Cu}$ elements in double treatments to observe the effect of each element on the distribution of another element in possible remedial treatments. There is lack of information on the interactions between $\mathrm{B}, \mathrm{F}$ and $\mathrm{Cu}$ elements when they are introduced into the wood and their effect on distribution of each element. We aimed to evaluate percentage retention levels of $\mathrm{B}, \mathrm{F}$ and $\mathrm{Cu}$ elements in wood after single and double treatments, to evaluate the effects of solution concentration and sapwood/heartwood formation on penetration of the elements in selected assay zones in treated wood specimens after extended period of time (7, 30, 60 and 90 days) after treatment processes.

\section{Materials and Methods}

Sugi wood (Cryptomeria japonica D. Don) sapwood and heartwood specimens (50 by 50 by $150 \mathrm{~mm}$ long) were air-dried to $12 \%$ target moisture content (MC). After conditioning in the climate chambers, a 10$\mathrm{mm}$ diameter hole (35-mm deep) was drilled on the narrow face of each specimen (Figure $1)$.

The solutions of DOT (di-sodium octoborate tetrahydrate), $\mathrm{NaF}$ (sodium fluoride) and $\mathrm{CuSO}_{4}$ (copper sulfate) (2\% and $5 \%$ ) were placed in each hole in the specimens. In single treatments, $6 \mathrm{ml}$ of each prepared solution was introduced into the holes of each specimen by gradually to make sure solutions spread thoroughly into wood structure. In double treatments, $3 \mathrm{ml}$ of each solution was inserted into the holes in the same way explained previously (Table 1). First, $3 \mathrm{ml}$ of each solution was added into the holes. After all solution was distributed into the wood structure, second application of the solutions $(3 \mathrm{ml})$ was made (DOT + $\mathrm{NaF}, \mathrm{DOT}+\mathrm{CuSO}_{4}$ and $\left.\mathrm{NaF}+\mathrm{CuSO}_{4}\right)$ The treatment hole was then plugged with a plastic cap, and the specimens were incubated at room temperature for 7, 30, 60 and 90 days. During the storage of the blocks, the specimens were placed in desiccators separately to prevent any moisture loss during the incubation period. 
At each time point, two wood specimens were removed, weighed and oven-dried. The specimens were sawn immediately to the three equal assay zones - assay zone 1, 2 and 3 (Figure 1).

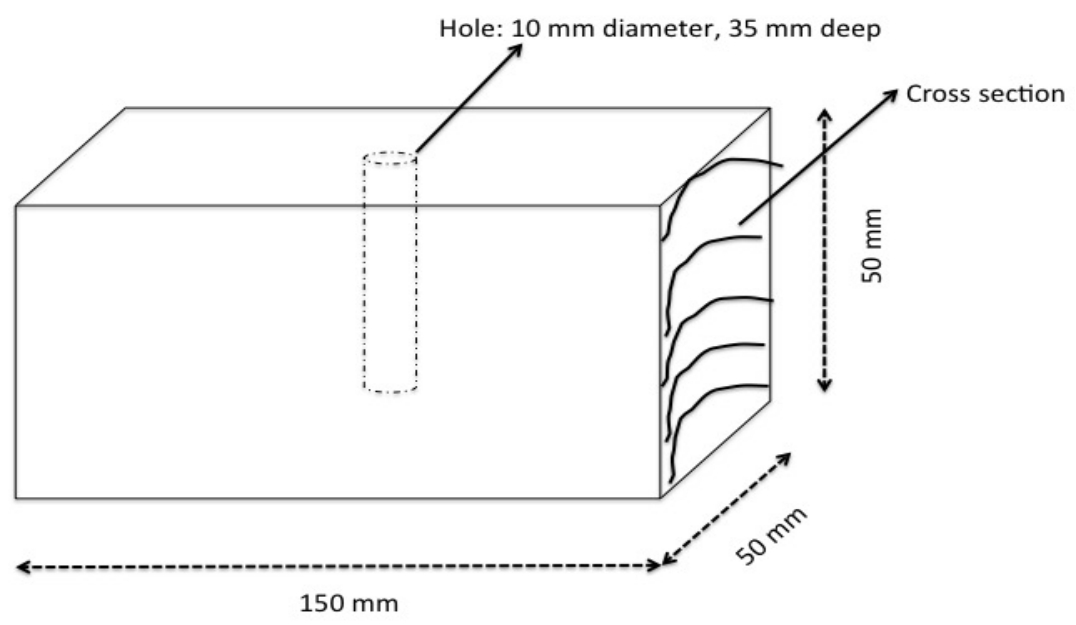

A $10-\mathrm{mm}$-diameter hole ( $35 \mathrm{~mm}$ deep) will be drilled on the narrow face of each specimen.

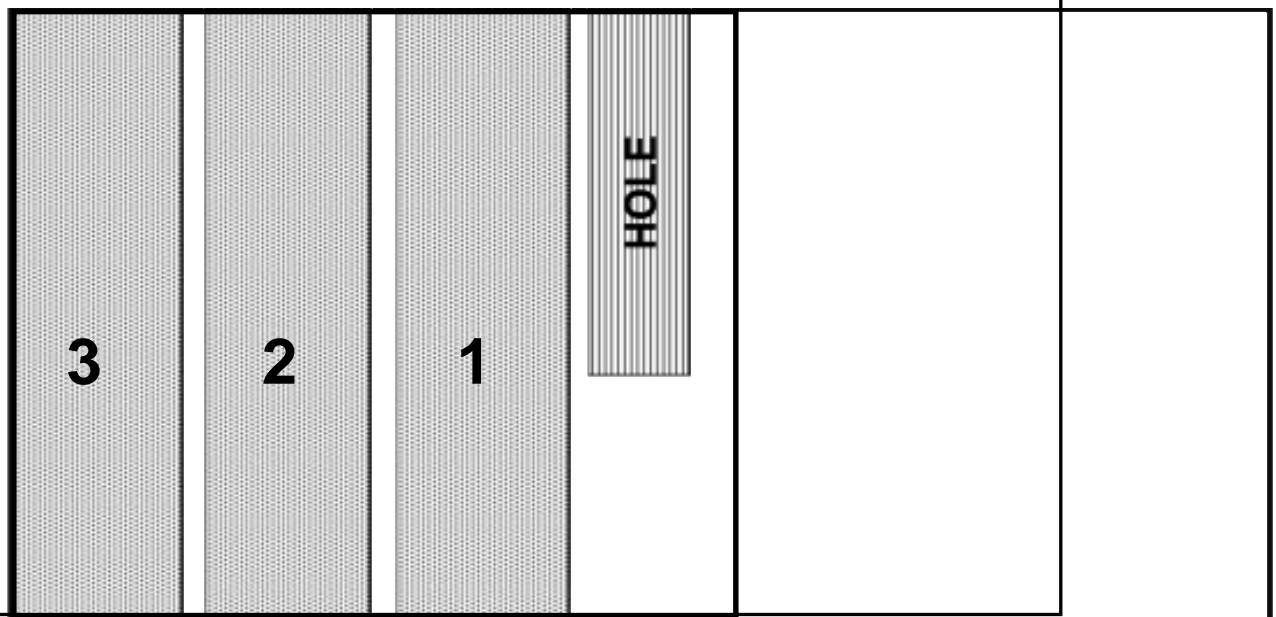

Figure 1. Representation of test specimens showing the treatment hole and pattern of cutting for assay zones (Assay zone 1 is the nearest part to the treatment hole, while assay zone 3 is the farthest part. Each zone is $22 \mathrm{~mm}$ in width.)

Table 1.Treatments followed in the study and amounts of treatment solutions placed into the holes in the specimens

\begin{tabular}{lc}
\hline Single treatments & Double treatments \\
\hline $2 \% \mathrm{DOT}(6 \mathrm{ml})$ & $2 \% \mathrm{DOT}(3 \mathrm{ml})+2 \% \mathrm{NaF}(3 \mathrm{ml})$ \\
\hline $5 \% \mathrm{DOT}(6 \mathrm{ml})$ & $5 \% \mathrm{DOT}(3 \mathrm{ml})+5 \% \mathrm{NaF}(3 \mathrm{ml})$ \\
\hline $2 \% \mathrm{NaF}(6 \mathrm{ml})$ & $2 \% \mathrm{DOT}(3 \mathrm{ml})+2 \% \mathrm{CuSO}_{4}(3 \mathrm{ml})$ \\
\hline $5 \% \mathrm{NaF}(6 \mathrm{ml})$ & $5 \% \mathrm{DOT}(3 \mathrm{ml})+5 \% \mathrm{CuSO}_{4}(3 \mathrm{ml})$ \\
\hline $2 \% \mathrm{CuSO}_{4}(6 \mathrm{ml})$ & $2 \% \mathrm{NaF}(3 \mathrm{ml})+2 \% \mathrm{CuSO}_{4}(3 \mathrm{ml})$ \\
\hline $5 \% \mathrm{CuSO}_{4}(6 \mathrm{ml})$ & $5 \% \mathrm{NaF}(3 \mathrm{ml})+5 \% \mathrm{CuSO}_{4}(3 \mathrm{ml})$ \\
\hline
\end{tabular}

The wood from the assay zones was then ground to pass a 20-mesh screen. The sawdust was subjected to a wet ashing procedure based on the AWPA A7-12 standard test method (AWPA, 2012) by using $70 \%$ nitric acid (14 ml, 25.8 molar). 
Accurately $0.5 \mathrm{~g}$ of sawdust sample was placed into a microwave digestion tube. The vessels with wood sawdust and acid were then placed into the carousel in the microwave oven (Anton Paar Microwave Digestion System-Multiwave GO, Austria). Following digestion procedure, the vessels were quantitatively brought up to $50 \mathrm{ml}$ with ultra-pure water. The extracts obtained from the microwave digestions were analyzed for boron (B) and copper $(\mathrm{Cu})$ by an ICP-AES Multitype ICP Emission Spectrometer (Shimadzu ICPE-9000, Japan). In fluoride (F) analyses, the supernatant was analyzed for $\mathrm{F}$ content using an $\mathrm{F}$ ion-selective electrode (F-ISE) based on the AWPA Standard A2 Method 7 (AWPA, 2006).

\section{Results}

\section{Boron (B) Distribution}

In general, sapwood specimens in single treatment showed more unique $\mathrm{B}$ element distribution considering the assay zones and incubation time when compared to the heartwood specimens (Figures 2 and 3). In the sapwood specimens with $2 \%$ DOT, at the first incubation period, B was present only in the

first assay zone representing the nearest part to the treatment hole. The 60 and 90-dayconditioning period of the respective specimens resulted in B diffusion through the farthest assay zones. In 5\% treatments, this trend was more apparent and also more B content was available in the zones compared to $2 \%$ DOT treatments. In the heartwood specimens, the assay zones 1 only showed B diffusion due to low permeability of the heartwood. In 5\% DOT treatments of heartwood specimens, even though increases in B element content were seen in the assay zones, in most cases the assay zone 3 did not contain B element.

In sapwood specimens, slight increases were noticed in the amount of B element when 2 and 5\% NaF combined with DOT solutions. The highest increases were seen in $5 \%$ DOT and NaF treatments in 90-dayincubated specimens when compared to $5 \%$ DOT-only treatments. In heartwood specimens treated with $2 \%$ solutions, the highest $\mathrm{B}$ element contents were obtained in 90-day-incubated specimens in comparison with single treatments. In 5\% treatments, in most cases elemental increases were available even though in some assay zones there were no changes when compared to single treatments. Considering the amounts of $\mathrm{B}$ element in both treatments, $\mathrm{NaF}$ had no adverse effect in the treatments in terms of B content in the assay zones.

Considering the effect of copper $(\mathrm{Cu})$ on $\mathrm{B}$ distribution, both increases and decreases were noticed in the amount of B element in the assay zones in sapwood specimens; however, almost no changes were seen in heartwood specimens in 2\% DOT and $\mathrm{CuSO}_{4}$ treatments when compared to $2 \%$ DOT only treatments. In 5\% DOT and $\mathrm{CuSO}_{4}$ treatments, the effect of $\mathrm{Cu}$ on $\mathrm{B}$ element distribution was clearer in comparison with $2 \%$ treatments. In most cases, presence of $\mathrm{Cu}$ element increased B contents in the assay zones when compared to single treatments in the respective zones. In heartwood specimens, even though B contents in the first and second assay zones were higher than the zones in single treatments, addition of $\mathrm{Cu}$ did not provide any $\mathrm{B}$ element increase in the third assay zones.

\section{Fluoride (F) Distribution}

It is clearly apparent that $\mathrm{F}$ contents in the assay zones were much higher than $B$ contents in all treatments and assay zones (Figures 2 and 3). With 2\% treatments, in sapwood specimens incubated for 30 and 60 days, the third assay zones did not contain any $\mathrm{F}$ content; however, in 7 and 90-dayincubated specimens, the respective zones included $\mathrm{F}$ element. In 5\% treatments, this phenomenon was seen in only 30-dayincubated specimens. In heartwood specimens, F contents were much less compared to sapwood specimens as expected. In 90-day incubated specimens, there was no $\mathrm{F}$ element in the third assay zone suggesting that heartwood formation did not permit the element distribution in this zone in heartwood when compared to sapwood. 

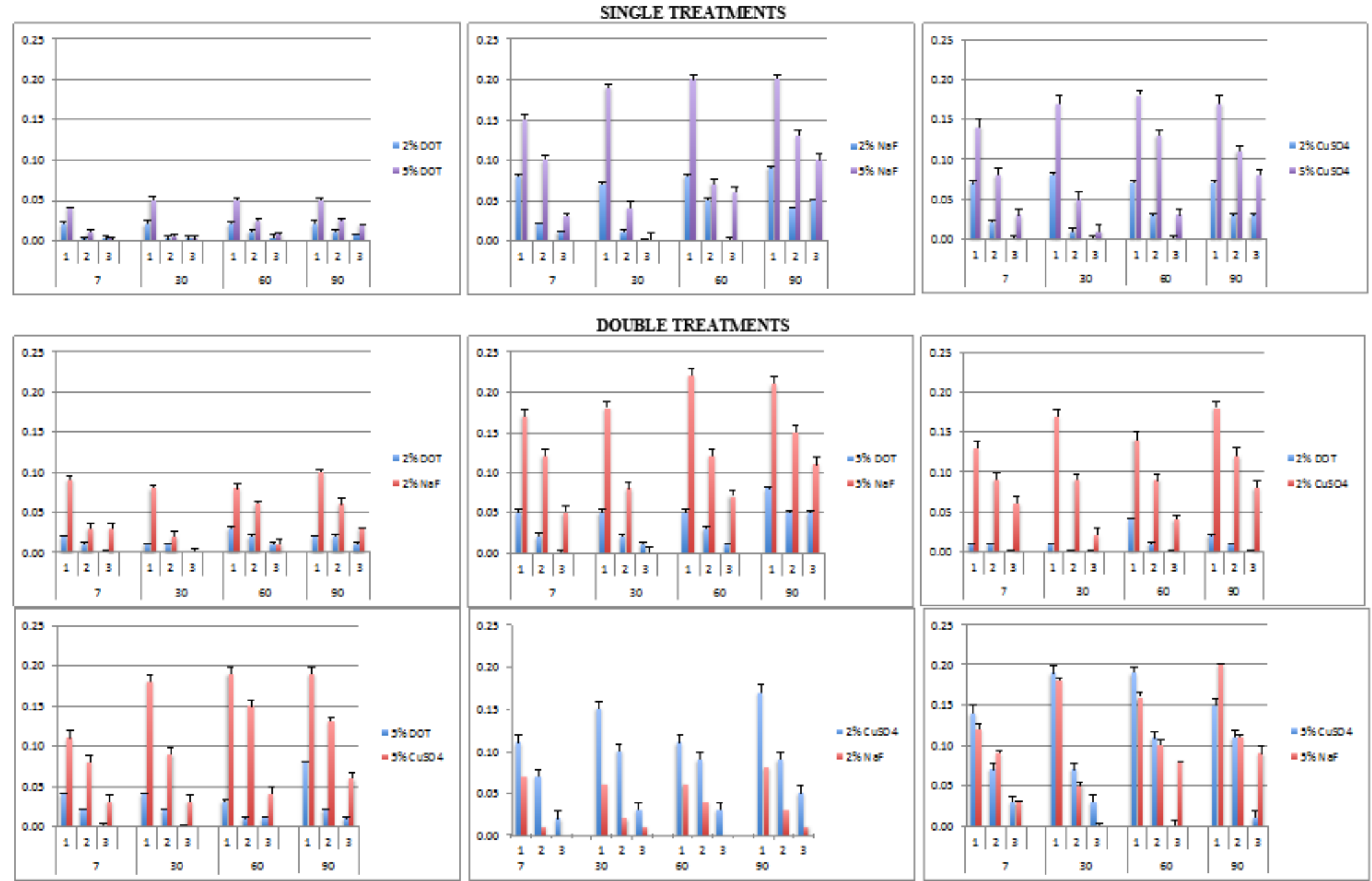

Figure 2. B (DOT treatments), $\mathrm{F}\left(\mathrm{NaF}\right.$ treatments) and $\mathrm{Cu}\left(\mathrm{CuSO}_{4}\right.$ treatments) contents (\%) in the assay zones $(1,2$ and 3$)$ away from the treatment hole in sapwood specimens conditioned for 7, 30, 60 and 90 days in single and double treatments $(n=2)$. 
SINGLE TREATMENTS
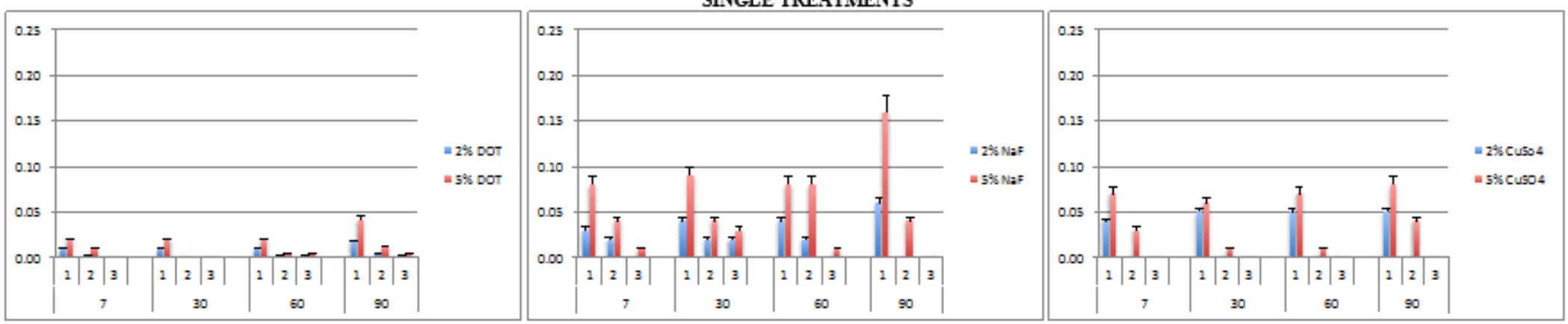

DOUBLE TREATMENTS
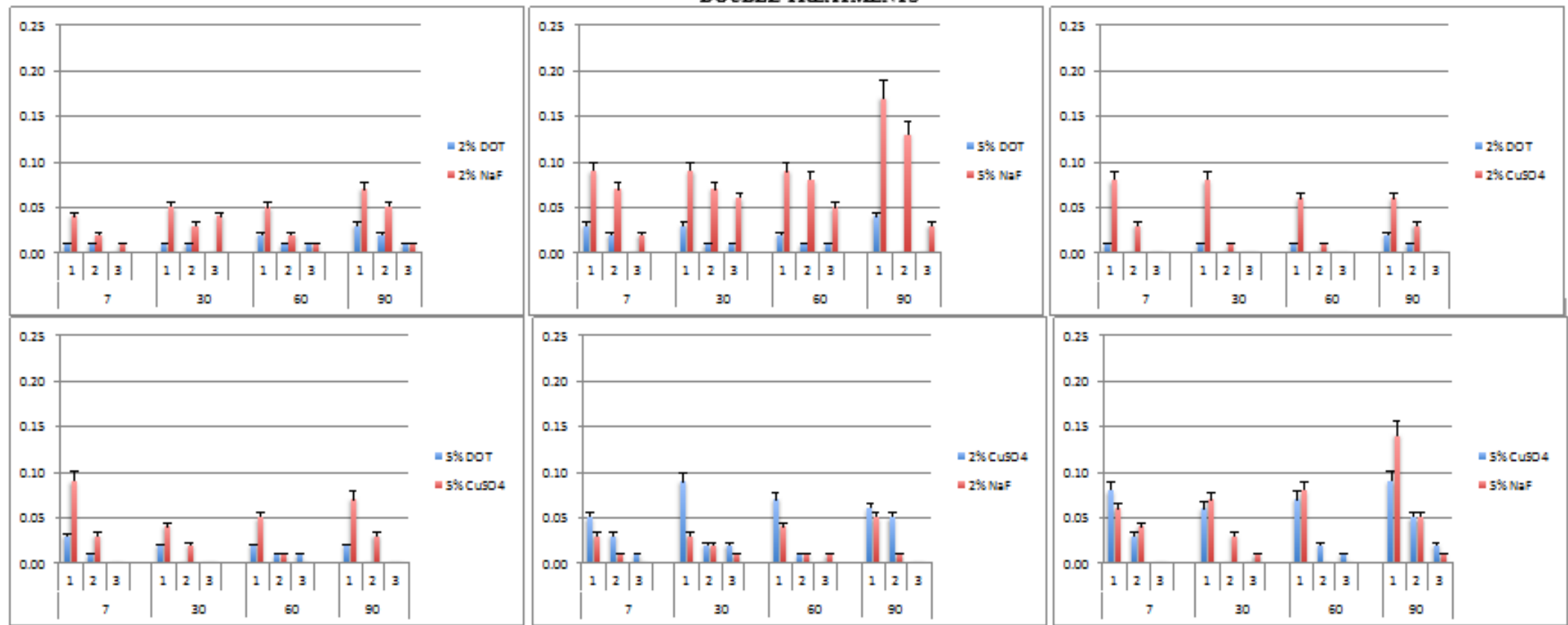

Figure 3. B (DOT treatments), $\mathrm{F}\left(\mathrm{NaF}\right.$ treatments) and $\mathrm{Cu}\left(\mathrm{CuSO}_{4}\right.$ treatments) contents (\%) in the assay zones $(1,2$ and 3$)$ away from the treatment hole in heartwood specimens conditioned for 7, 30, 60 and 90 days in single and double treatments $(n=2)$. 
The results showed that the presence of $\mathrm{B}$ element did help in obtaining higher $\mathrm{F}$ content in double treatments when compared to single treatments in sapwood specimens treated with both 2 and 5\% solutions. However, slight changes were noticed in terms of increased $\mathrm{F}$ contents in the assay zones in heartwood specimens in comparison with sapwood specimens.

Incorporation of $\mathrm{Cu}$ adversely affected $\mathrm{F}$ content in double treatments when compared to single $\mathrm{NaF}$ treatments. In almost all assay zones, $\mathrm{F}$ content decreased due to presence of $\mathrm{Cu}$ element in both sapwood and heartwood specimens suggesting maximum interaction between the two compounds and no potential use for using both at the same time.

\section{Copper ( $\mathrm{Cu}$ ) Distribution}

In sapwood specimens, no $\mathrm{Cu}$ contents in $2 \%$ single treatments were seen in the third assay zones expect for 90-day-incubated specimens; however, $5 \%$ treatments resulted in distribution of $\mathrm{Cu}$ element in the respective zones. In heartwood specimens treated with $2 \% \mathrm{CuSO}_{4}$ only, no $\mathrm{Cu}$ element was available in the second and third assay zones; however in 5\% treatments, $\mathrm{Cu}$ was available in the first and second assay zones only whilst the third assay zones were lack of $\mathrm{Cu}$ distribution (Figures 2 and 3 ).

The presence of DOT in 2\% double treatments helped in obtaining higher $\mathrm{Cu}$ element in the assay zones. Particularly $\mathrm{Cu}$ appeared in the third assay zones even though in single treatments those zones did not include any $\mathrm{Cu}$ element. In 5\% treatments, one single decrease in $\mathrm{Cu}$ content was seen in the first assay zone of the sapwood specimen incubated for 7 days; however, all the other cases resulted in higher $\mathrm{Cu}$ contents in those treatments. In heartwood specimens with 2 and 5\% solutions, it seemed that B in general was helpful in increased $\mathrm{Cu}$ content in the first assay zones only and $\mathrm{Cu}$ was not able to reach to the third assay zones along with $\mathrm{B}$.

Considering the effect of $\mathrm{F}$ on $\mathrm{Cu}$ content, the interaction was clearer in $2 \%$ treatments when compared to $5 \%$ treatments. In $2 \%$ single treatments, no $\mathrm{Cu}$ was available in the third assay zones; however, the presence of $\mathrm{F}$ element in double treatments resulted in $\mathrm{Cu}$ contents in the respective zones and also $\mathrm{Cu}$ content increased in all assay zones in comparison with single treatments. In most cases, in 5\% treatments there were no considerable changes in terms of $\mathrm{Cu}$ content; even though in some small cases slight increases were noticed. Similar scenario was seen in heartwood specimens and slight improvements were obtained particularly in $5 \%$ treatments suggesting that increased $\mathrm{Cu}$ content might have resulted in precipitation or fixation in the specimens.

\section{Discussion}

The motivation in the present study was to evaluate the diffusion properties of DOT, $\mathrm{NaF}$ and $\mathrm{CuSO}_{4}$ wood preservatives considering the possible effects of $\mathrm{B}, \mathrm{F}$ and $\mathrm{Cu}$ elements on the element distribution. Fluoride and B elements are not strongly fixed to the wood, they may remain at protective levels for many years following remedial treatments. Copper element, on the other and, can diffuse into wet wood; although the degree of diffusion is more limited than $\mathrm{F}$ and $\mathrm{B}$ elements.

Remedial treatments can be most efficient as long as the preservative active compounds are mobile enough to penetrate into the wood. In order to achieve better diffusion and permanence, generally preservative formulations with one ingredient that fixes in the wood and another that diffuses are preferred. The diffusible one penetrates deeply into the sapwood via moisture in the wood. Copper element in such remedial treatments remains less mobile element; however, B is a typical diffusible element along with $\mathrm{F}$ that was generally employed in previous remedial treatments (Lebow et al., 2014). They studied synergy and diffusion with borax- $\mathrm{Cu}(\mathrm{OH})_{2}$ to protect wood in groundline. Their studies showed that although $\mathrm{Cu}$ movement was not big as that of B element, significant movement occurred. They also suggested that the long-term protection is due to mainly $\mathrm{Cu}$ in the groundline and below ground areas, and to both $\mathrm{B}$ and $\mathrm{Cu}$ in above-ground areas.

Morrell et al. (2005) stated that the potential for interactions between protective elements is inadequately studied and information will be needed for better 
understanding the interactions between the chemicals once they diffuse into the wood. When they treated wood blocks with 2 and $5 \% \mathrm{NaF}$ or $\mathrm{CuSO}_{4}$ solutions in single and double treatments and evaluated treatment uptakes and leaching rates of the elements. They stated that sequential soaking with $\mathrm{Cu}$ and $\mathrm{F}$ does not seem to produce a fixed product in the wood. Fluoride appeared in their study to increase $\mathrm{Cu}$ uptake; however, some of the increased $\mathrm{Cu}$ might be a result of the loss of $\mathrm{F}$ into the $\mathrm{Cu}$ solution. They found that $\mathrm{F}$ did not appear to have an effect on $\mathrm{Cu}$ uptake since they discovered higher levels of residual $\mathrm{Cu}$ in wood initially treated with $\mathrm{F}$. Their findings stated that sequential soaking treatments with $\mathrm{F}$ and $\mathrm{Cu}$ solutions may have some benefits and these might be slight.

In the recent study, we found that $\mathrm{F}$ had no adverse effects on B diffusion; however, improvements in terms of enhanced B diffusion were even limited. Similarly, effect of $\mathrm{Cu}$ on $\mathrm{B}$ element diffusion was not clear since we obtained both decreased and increased B content in the assay zones. Considering these results, it might be useful to employ those compounds together due to possibly increased biological efficacy against biodeterioration. Interestingly the effect of B on $\mathrm{F}$ diffusion was similar to the effect of $\mathrm{F}$ on $\mathrm{B}$; however, presence of $\mathrm{Cu}$ negatively affected $\mathrm{F}$ content in double treatments. We suggested that maximal interaction between $\mathrm{Cu}$ and $\mathrm{F}$ resulted in this phenomenon and probably partial fixation or precipitation of $\mathrm{Cu}$ might be responsible. Thus, the potential use of both compounds at the same time might be resulted in less $\mathrm{F}$ diffusion in wood. When incorporated with $\mathrm{B}, \mathrm{Cu}$ diffusion improved and $\mathrm{Cu}$ was more available in the third assay zones; however, the effect of $\mathrm{F}$ was not obvious as much as B element. Freeman (2013) reviewed that in CCB (copper/chromium/boron) wood preservative, $\mathrm{B}$ element entirely penetrates and enhances $\mathrm{Cu}$ penetration. Small amounts of B may significantly improve penetration of $\mathrm{Cu}$ based preservatives. The presence of $\mathrm{B}$ delays $\mathrm{Cu}$ precipitation, resulting in deeper penetration and distribution of $\mathrm{Cu}$ across the cell walls. In addition, the $\mathrm{Cu}$ reduces $\mathrm{B}$ leaching via partial fixation.

\section{Conclusion}

Except for the adverse effects of $\mathrm{Cu}$ on $\mathrm{F}$ element diffusion, there was no negative effect of $\mathrm{B}, \mathrm{F}$ and $\mathrm{Cu}$ elements on each other in the treatments. In most cases, incorporation of the elements improved the diffusion of each one. The potential use of the elements in dual treatments to increase diffusion might be useful; however, the further studies are needed to evaluate the stability and presence of the elements in the wood in long term and resistance against leaching in harsh conditions.

\section{Acknowledgements}

The first author acknowledges the support from RISH, Kyoto University, Kyoto, Japan under the Visiting Professor Program in 2018. The authors thank Mr. Akio Adachi for preparing the wood specimens.

\section{References}

American Wood Protection Association (AWPA). (2006). Standard A2. Analysis of waterborne preservatives and fire-retardant formulations. Method 7. Determination of fluoride in wood and solutions. In: AWPA Book of Standards. AWPA, Selma, AL., 236-237.

American Wood Protection Association (AWPA). (2012). Standard wet ashing procedures for preparing wood for chemical analyses. Standard A7-12. In: Book of Standards. AWPA, Birmingham, Alabama, 224.

Cooper, P. A. (1991). Cation exchange adsorption of copper on wood. Wood Protection, 1(1), 914.

Freeman, M. H. (2013). The concept of copper and boron synergy: why copper naphthenate and borates are a couple made in heaven. In: Proceedings of The $44^{\text {th }}$ Annual Meeting of IRG-WP, Stockholm, Sweden, 16-20 June 2013, IRG-WP 13-30622, 19

Freitag, C. \& Morrell, J. J. (2005). Development of threshold values for boron and fluoride in non-soil contact applications. Forest Products Journal, 55(4), 97-101.

Kartal, S. N., Terzi, E. \& Yoshimura, T. (in press) Performance of fluoride and boron compounds against drywood and subterranean termites and decay and mold fungi. Journal of Forestry Research.

Lebow, S. \& Anthony, R. W. (2012). Guide for use of wood preservatives in historic structures. 
General Technical Report FPL-GTR-217, Madison, WI: U.S. Department of Agriculture, Forest Service, Forest Products Laboratory, 59.

Lebow, S., Woodward, B., Abbot, B. \& West, M. (2014). Synergy and diffusion with a boraxcopper hydroxide groundline preservative: 20 . year update. In Proceedings of AWPA (American Wood Protection Association) $110^{\text {th }}$ Annual Meeting, May 4-6, 2014 Newport Beach, California, USA, 88-94.

Morrell, J. J., Freitag, C. M. \& Chen, H. (2005). Sequential treatments with fluoride and copper: Effects of solution concentration and dipping time on treatment. Forest Products Journal, 55(7/8), 57-62.
Pavia, K. J. (2006). A review of double-diffusion wood preservation suit- able for Alaska. Gen. Tech. Rep. PNW-GTR-676. Portland, OR: U.S. Department of Agriculture, Forest Service, Pacific Northwest Research Station, 23

Tascioglu, C., Umemura, K., Kusuma, S. S. \& Yoshimura, T. (2017). Potential utilization of sodium fluoride $(\mathrm{NaF})$ as a biocide in particleboard production. Journal of Wood Science, 63(6), 652-657.

Terzi, E., Kartal, S. N., Gerardin, P., Ibanez, C. M. \& Yoshimura, T. (2017). Biological performance of particleboard incorporated with boron minerals. Journal of Forest Research, 28(1), 195-203. 